\title{
BUELLIELLA INDICA (DOTHIDEOMYCETES), A NEW LICHENICOLOUS SPECIES FROM INDIA
}

\author{
P. SINGH ${ }^{*}$ and K. P. SingH \\ Central Regional Centre, Botanical Survey of India \\ 10-Chatham Lines, Allahabad 211 002, Uttar Pradesh, India; *E-mail: pushpisingh08@gmail.com
}

(Received 6 April, 2018; Accepted 3 September, 2018)

A new lichenicolous fungus Buelliella indica colonising on the thallus of Graphis longiramea is described from the state of Nagaland, a part of the Indo-Burma biodiversity hotspot region in India. It is characterised by its brown epihymenium, much smaller ascospores with dimensions of 11.5-13.8 × 4.8-6 $\mu \mathrm{m}$ and the new host Graphis.

Key words: Buelliella, India, lichenicolous fungi, taxonomy

\section{INTRODUCTION}

The lichenicolous Dothidealean genus Buelliella established by Fink (1935) is represented by 13 species viz. B. colombiana Etayo, B. dirinariae Diederich, $B$. eximia Kalb et Hafellner, B. heppiae van den Boom, B. inops (Triebel et Rambold) Hafellner, ${ }^{*}$ B. lecanorae Suija et Alstrup, ${ }^{*} B$. minimula (Tuck.) Fink, B. nuttallii (Calk. et Nyl.) Fink, B. physciicola Poelt et Hafellner, B. poetschii Hafellner, ${ }^{*} B$. protoparmeliopsis Etayo et Pérez-Ortega, B. pusilla Hafellner and B. trypethelii (Tuck.) Fink ex Hafellner in the world (Aptroot et al. 1997, Etayo 2002, Hafellner 1979, 1985, Hafellner et al. 2002, 2008, Kalb 1990, Pérez-Ortega and Etayo 2010, Santesson 1994, Suija and Alstrup 2004, van den Boom 2010). Of these, 3 species marked by an asterisk $\left(^{*}\right)$ above occur in India. The genus is characterised by its apothecioid ascomata when mature, dark brown paraplectenchymatous exciple, bitunicate ascus, I-, and thin walled, brown, pigmented, 2-celled ascospores. Lichenicolous fungi in India have not been paid proper attention and so far, 104 species are known (Joshi et al. 2016, Singh et al. 2017). However, in last few years, these fungi have received considerable attention by a few researchers (Joseph and Sinha 2015, Joshi et al. 2016, Singh et al. 2017, Zhurbenko 2013) who have described new species and prepared a checklist of lichenicolous fungi of the country. During the course of lichenological studies on graphidoid lichens from northeastern states of India under SERB project, an interesting lichenicolous fungus Buelliella indica has been discovered from the collections of Nagaland, hitherto not reported on the host genus Graphis. This species is clearly distinct from all other known lichenicolous species of Buelliella and therefore, deserves to be described here as new species. 


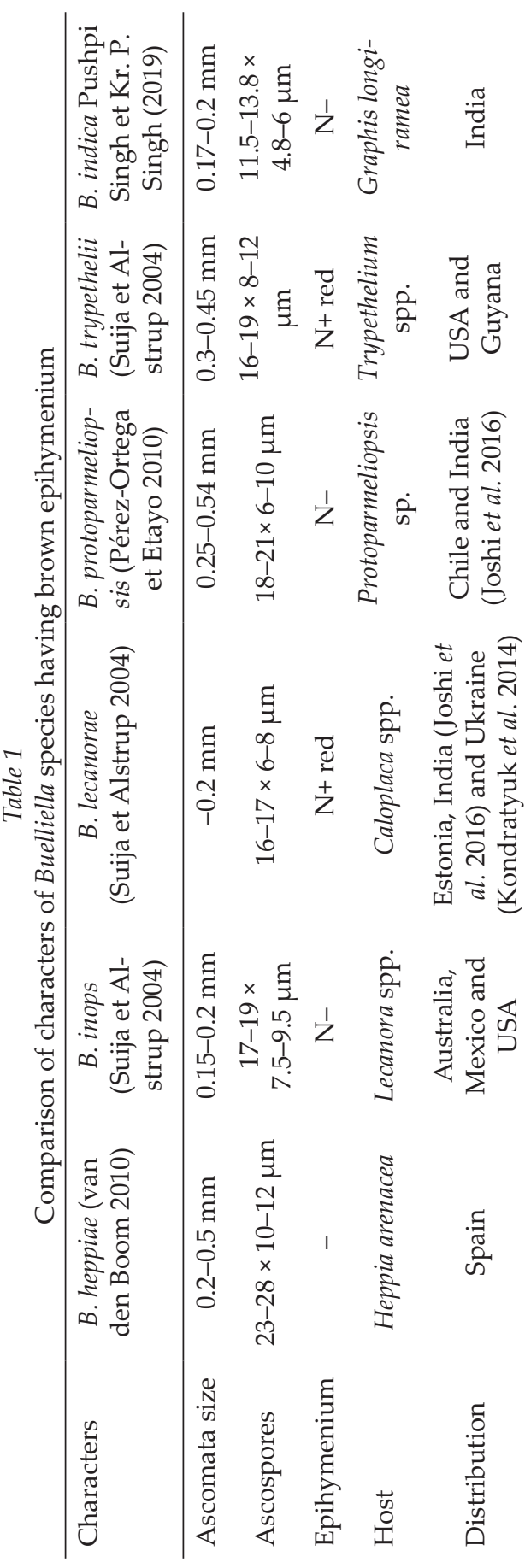

\section{MATERIALS AND METHODS}

The specimens collected from Nagaland, India, deposited in ASSAM herbarium was examined morphologically and anatomically. Morphological characters of reproductive structures and their colour, size and shape were examined under a stereomicroscope (Nikon SMZ 1500). Thin hand-cut sections of ascomata were mounted in water, $50 \% \mathrm{HNO}_{3}(\mathrm{~N})$ and $10 \% \mathrm{KOH}$ (K) and examined under a compound microscope (Nikon Eclipse 50i). All anatomical measurements were made in water mounts. Ascomata and ascospores were stained with Lugol's solution to check the amyloid reaction.

\section{RESULTS AND DISCUSSION}

Buelliella indica Pushpi Singh et Kr. P. Singh, spec. nova

(Fig. 1)

MycoBank no.: MB 824735.

Differs from other species of Buelliella by its brown epihymenium, smaller, 11.5-13.8 $\mu \mathrm{m}$ long ascospores and lichenicolous habit on the thallus of Graphis longiramea.

Type: India. Nagaland, Phek district, Chozuba road, on Graphis longiramea, alt. 1500-1700 m, coll.: K. P. Singh and G. P. Sinha (2971), 16.09.1998 (holotype: ASSAM). 
Ascomata apothecioid, rounded, solitary, rarely grouped, sessile, black, 0.17-0.20 mm wide; apothecial margin thin, inconspicuous to be excluded, concolorous with the disc; disc black, epruinose, plane to slightly concave; exciple paraplectenchymatous, dark brown, 15-20 $\mu \mathrm{m}$ thick, continuous below the subhymenium, K-; hymenium hyaline to pale brown, 40-50 $\mu \mathrm{m}$ high, I-; epihymenium brown, $\mathrm{K}-$, $\mathrm{N}-$; subhymenium hyaline; paraphysoids thin, up to $1.5-2 \mu \mathrm{m}$ wide, branched and anastomosing, widened and brown pigmented apically; asci 8-spored, cylindrical to clavate, bitunicate, with distinct ocular chamber when young, I-, 30-40 × 16-20 $\mu \mathrm{m}$; ascospores initially hyaline, becoming pale brown, 1-septate, rarely with 1-2 additional septa, smooth, thin walled, constricted at the medium septum, upper cell broader than lower cell, without ornamentation or perispore, with few oil droplets in each cell, 11.5-13.8 × 4.8-6 $\mu \mathrm{m}$; conidiomata not observed.

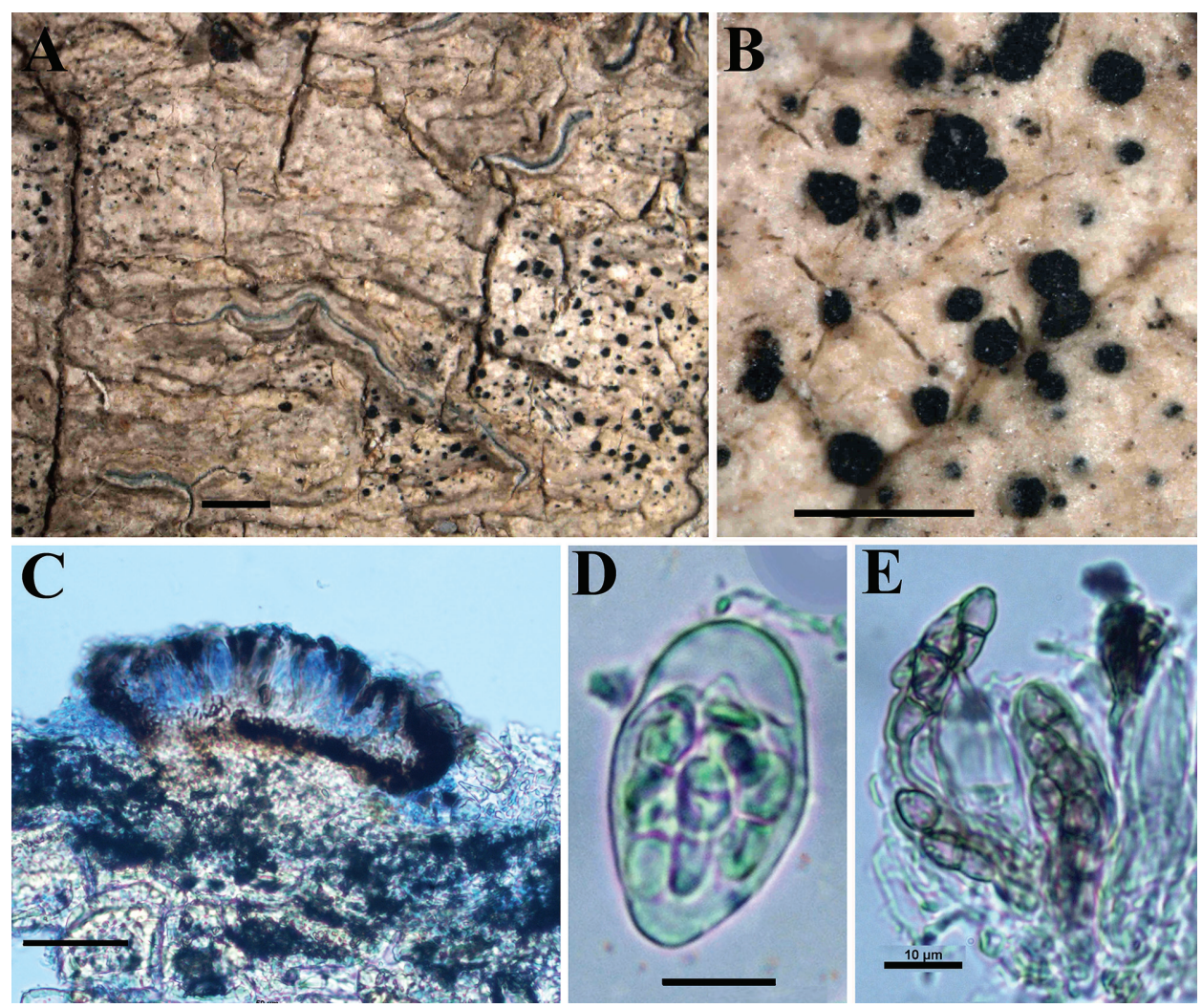

Fig. 1. Buelliella indica (holotype). $\mathrm{A}-\mathrm{B}=$ ascomata of Buelliella indica on Graphis longiramea; $\mathrm{C}=$ cross section through an ascoma; $\mathrm{D}=$ ascospores in an ascus; $\mathrm{E}=$ mature ascospores in asci. Scale bar: $\mathrm{A}-\mathrm{B}=1 \mathrm{~mm} ; \mathrm{C}=100 \mu \mathrm{m} ; \mathrm{D}-\mathrm{E}=10 \mu \mathrm{m}$ 
Host: Lichenicolous on thallus and ascomata of Graphis longiramea. It seems to be commensalistic on host and does not harm the host.

Etymology: The species epithet refers to the name of the country where the new species is described from.

Ecology and distribution: The new species is known only from the type locality, growing abundantly on the host species Graphis longiramae, scarcely distributed in the area.

Taxonomic remarks: So far, five species, viz. Buelliella heppiae, B. inops, B. lecanorae, B. protoparmeliopsis and B. trypethelii have been reported to have brown epihymenium. The new species also has brown epihymenium and can readily be distinguished from the above-mentioned species by its smaller ascospores and its host. The comparison of some selected characters of Buelliella species, possessing brown epihymenium along with new species is provided in Table 1.

Acknowledgements - The authors are thankful to Director, Botanical Survey of India, Kolkata for encouragement and to Head of Office, Botanical Survey of India, Central Regional Centre, Allahabad for facilities. We thank two anonymous reviewers for useful comments and suggestions on the manuscript. One of the authors (PS) is thankful to Science and Engineering Research Board (SERB) under N-PDF scheme (PDF/2016/002035) for the financial assistance.

\section{REFERENCES}

Aptroot, A., Diederich, P., Sérusiaux, E. and Sipman, H. J. M. (1997): Lichens and lichenicolous fungi from New Guinea. - Bibl. Lichenol. 64: 1-220.

Etayo, J. (2002): Aportación al conocimiento de los hongos liquenícolas de Colombia. - Bibl. Lichenol. 84: 1-154.

Fink, B. (1935): The lichen flora of the United States. - University of Michigan Press, Ann Arbor, 426 pp.

Hafellner, J. (1979): Karschia. Revision einer Sammelgattung an der Grenze von lichenisierten und nichtlichenisierten Ascomyceten. - Beih. Nova Hedwigia 62: 1-248.

Hafellner, J. (1985): Studien über lichenicole Pilze und Flechten IV. Die auf BrigantiaeaArten beobachteten Ascomyceten. - Herzogia 7: 163-180.

Hafellner, J., Herzog, G. and Mayrhofer, H. (2008): Zur Diversität von lichenisierten und lichenicolen Pilzen in den Ennstaler Alpen (Österreich: Steiermark, Oberösterreich). - Mitt. Naturwiss. Verein. Steiermark 137: 131-204.

Hafellner, J., Triebel, D., Ryan, B. D. and Nash III, T. H. (2002): On lichenicolous fungi from North America II. - Mycotaxon 84: 293-329.

Joseph, S. and Sinha, G. P. (2015): The lichenicolous species of Melaspilea (Melaspileaceae) in India. - Taiwania 60: 18-22. https://doi.org/10.6165/tai.2015.60.18

Joshi, Y., Falswal, A., Tripathi, M., Upadhyay, S., Bisht, A., Chandra, K., Bajpai, R. and Upreti, D. K. (2016): One hundred and five species of lichenicolous biota from India: an updated checklist for the country. - Mycosphere 7(3): 268-294. https://doi.org/10.5943 /mycosphere/7/3/3 
Kalb, K. (1990): Lichenes neotropici. - Fasc. XI (No. 451-475).

Kondratyuk, S., Lőkös, L. and Hur, J. S. (2014): New lichen-forming and lichenicolous fungi from Ukraine. - Acta Bot. Hung. 56(3-4): 361-368. https://doi.org/10.1556/ABot.56 .2014.3-4.11

Pérez-Ortega, S. and Etayo, J. (2010): Labrocarpon gen. nov. for Melaspilea canariensis, with the description of Buelliella protoparmeliopsis sp. nov. from South America. Lichenologist 42(3): 271-276. https://doi.org/10.1017/S0024282909990624

Santesson, R. (1994): Fungi lichenicoli exsiccati. Fasc. 7 and 8 (Nos 151-200). - Thunbergia 21: $1-18$.

Singh, P., Joshi, Y. and Singh, K. P. (2017): A new lichenicolous species of Melaspilea (Melaspileaceae, Arthoniales) from India. - Acta Bot. Hung. 59(3-4): 439-443. https://doi .org/10.1556/034.59.2017.3-4.9

Suija, A. and Alstrup, V. (2004): Buelliella lecanorae, a new lichenicolous fungus. - Lichenologist 36(3-4): 203-206. https://doi.org/10.1017/S0024282904014239

van den Boom, P. P. G. (2010): New or interesting lichens and lichenicolous fungi of Gran Canaria (Canary Islands, Spain). - Willdenowia 40: 359-367. https://doi.org/10.3372/wi .40 .40215

Zhurbenko, M. P. (2013): A first list of lichenicolous fungi from India. - Mycobiota 3: 19-34. https://doi.org/10.12664/mycobiota.2013.03.03 
